\title{
Characteristics of Social Work with Children with Disabilities in Great Britain
}

\author{
Rizak Iryna \\ Postgraduate \\ Borys Grinchenko Kyiv University (Ukraine, Kyiv)
}

\begin{abstract}
The article describes the features of social work for children with disabilities in the UK. Defined the concept of children with disabilities. Described the interpretation of the concept of children with disabilities according to the medical and social model. Presented the main structures that can provide social services in the UK to children with disabilities. Analyzed the peculiarities of British social work with children with disabilities in the activities of the Centers for Social Services. Determined the main types of social services provided by such centers are described. The concept of independent living and activities of the centers independent living are described. The types of services provided to children with disabilities and their families (information; counseling; legal; housekeeping services, home support, leisure organization, guardianship services) are identified. The programs implemented at the state level to provide support are given and providing social assistance to children with disabilities and their families. Pointed out the orientation of state programs and their provision of social services to improve the educational outcomes of children with disabilities. The main directions of social work for children with disabilities in the United Kingdom are described. Characterized medical and social work (basic care) and social work with children and families.

Key words: children with disabilities, social services, types of social services in the UK, forms of social work for children with disabilities, the concept of independent living, British programs to support children with disabilities.
\end{abstract}

Актуальність дослідження. Актуальним питанням та нагальною соціальною проблемою українського суспільства є стан здоров’я дітей та молоді. За даними звіту 2018 року Міністерства соціальної політики та Міністерства охорони здоров’я України кількість дітей з інвалідністю з 2015 по 2019 рр. збільшилась (2015 р. - 151,1 тис. осіб; 2016 р. - 153,5; 2017 p. - 156,1; 2018 p. - 159,0; 2019 р. - 161,6 тис. осіб). Статистика свідчить, що на 01.01.2019 в Україні налічується 161600 осіб дітей з інвалідністю до 18 років [2].

Досить розгалужене сучасне законодавче забезпечення соціальної роботи з дітьми з інвалідністю не вирішує низку сучасних проблем та актуальних питань, які стосуються недосконалості соціальної роботи 3 даною категорією. А саме, важливим $\epsilon$ вдосконалення та пошук шляхів ефективності рівня соціальної роботи 3 дітьми 3 інвалідністю, розширення та вдосконалення моделей, методів та форм соціальнопедагогічної роботи з такими дітьми. 
Прагнення України до побудови високих соціальних стандартів, розширення іï співпраці та взаємодії з зарубіжними країнами визначають актуальність вивчення зарубіжного досвіду соціальної та соціально-педагогічної роботи з дітьми з інвалідністю. А саме, багаторічний досвід соціальної роботи з дітьми з інвалідністю Великої Британії, що характеризується створенням потужної мережі наукових доробок та досліджень.

Вивчення досвіду соціальної роботи з дітьми з інвалідністю у Великій Британії, його особливостей, специфіки, основних технологій соціальної роботи 3 даною категорією, побудовою соціальних програм може стати корисним для української науки та впровадження елементів такого досвіду в українську систему практичної соціальної роботи.

Вивченню зарубіжного досвіду соціальної роботи присвячено низку досліджень: Л. Гордієнко (соціалізація молоді Великобританії); О Романовська О. (фостерна сім’я Великої Британії як соціальне середовище для дитини); М. Зубілевич (гендерне виховання у Великобританії); М. Гурій (громадське виховання школярів у Великій Британіі); І. Братусь (робота з юними матерями в США та Великобританії); О. Загайко (підготовка соціальних працівників в Англії); Н. Мороз (система виховної роботи у навчальних закладах Великобританії); О. Бойко (професійна підготовка фахівців із соціальної роботи третього рівня вищої освіти у Великій Британії).

Окремі аспекти соціальної роботи з дітьми з інвалідністю розглянуто у роботах зарубіжних науковців Дж. Аделлізі, Д. Бейкер, У. Берніс, П. Бюрк, А. Веб, М. Вергас, Д. Гловер, Т. Губі, К. Девіз, Джк. Кінгслей, М. Леповскі, Л. Мавис, Б. Мондей, М. Олівер, Дж. Паркер, Дж. Скотт, Н. Тімс, К. Франкель, С. Ханвай, К. Химпрей, М. Хорізон, Л. Шульман, П. Янг.

В останнє десятиріччя в Україні здійснено низку досліджень, які присвячені роботі 3 дітьми 3 інвалідністю, зокрема: інтегрування дітей 3 функціональними обмеженнями в сучасне середовище (Н. Мирошніченко, В. Скрипник); реабілітація осіб 3 обмеженнями життєдіяльності ( $Є$ Агеєв, Л. Боброва, В. Бондар, Г. Гаврюшенко, О. Граборов, Н. Сайко, О. Поліщук, М. Чайковський, А. Шевцов); соціально-педагогічна підтримка дітей з інвалідністю (О. Міщенко, В. Тесленко); соціально-педагогічна робота 3 дітьми з особливими потребами (І. Іванова); корекція різних порушень у дітей з вадами розвитку (О. Зинов’єв, А. Кіссе, М. Мога, В. Синьов); формування соціальної 
компетентності осіб з обмеженими можливостями (В. Ляшенко, О. Позднякова, О. Хорошайло); соціальна підтримка батьків дітей 3 інвалідністю (Н. Грабовенко, I. Макаренко, Т. Соловйова, Т. Чечко) тощо.

Проте аспект використання британського досвіду, форм та методів соціальної роботи з дітьми з інвалідністю в Україні не знайшов достатнього відображення в теорії та методиці соціальної роботи.

Тому метою нашої статmі обрано деталізацію форм соціальної роботи з дітьми з інвалідністю у Великій Британії, як можливого досвіду використання в українській соціальній роботі.

Виклад основного матеріалу. Соціальна система Великої Британії сформувалась та розвивалась шляхом модифікації, розширення і перетворилась на важливий сектор надання соціальних послуг. Сучасна соціальна політика даної держави пронизує всі сфери суспільного життя, а саме вона пов'язана з економічною, освітньою, культурною, медичною, екологічною та іншими сферами.

Інвалідність у дітей означає істотне обмеження життєдіяльності, вона призводить до соціальної дезадаптації, що зумовлена порушеннями в розвитку, труднощами в самообслуговуванні, спілкуванні, навчанні, оволодінні професійними навичками. Освоєння дітьми з інвалідністю соціального досвіду, включення їх в існуючу систему суспільних відносин вимагає від суспільства значних організаційних, економічних і правових заходів.

У Великій Британії поняття «діти з інвалідністю» розглядається з точки зору двох моделей, а саме: медичної та соціальної моделі.

3 точки зору медичної моделі «діти з інвалідністю - це неповнолітні особи, які мають фізичні або психологічні хвороба/порушення, що обмежує здатність або діяльність дитини і може знизити якість їхнього життя.

Соціальна модель розглядає «дітей з інвалідністю - неповнолітні особи, які стикаються з соціальними бар'єрами, що утруднюють їх індивідуальні можливості та створюють особливі потреби» $[11$, с. $3 ; 7 ; 8$, с. 72-76; 12].

Діяльність британської соціальної роботи з особами з інвалідністю, включаючи і дітей 3 інвалідністю будується на міжнародній класифікації функціонування, інвалідності та здоров’я (МФК). Вона використовується як інструмент для планування 
та формування соціальної політики, щодо осіб з інвалідністю, в тому числі і дітей 3 інвалідністю.

Система соціальної роботи з дітьми з інвалідністю у Великобританії пов'язана 3 наданням соціальних послуг даній категорії клієнтів. Соціальні послуги в даній країні можуть надаватись дітям з інвалідністю, а саме тим які мають фізичні, розумові вади та хронічні захворювання. Соціальні послуги надаються такими структурами як: департаментами соціальної роботи, місцевою владою, волонтерськими (громадськими) організаціями. При цьому всі перераховані організації мають спільну мету та ставлять однопланові завдання, які спрямовані на допомогу дітям з інвалідністю вести повноцінне життя та максимально сприяти їх соціалізації та інтеграції у громаду.

Крім перерахованих вище структур, значне місце при наданні соціальних послуг дітям $з$ інвалідністю та сім'ям, що їх утримують і виховують надається Центрам соціальних служб Великобританії.

Центри соціальних служб у Великобританії переважно надають допомогу у дома, в денних центрах, денних школах. У всіх цих установах основна увага приділяється формуванню та навчанню дітей з інвалідністю, розвиток у них навичок спілкування, навчанню правилам поведінки у різних соціумах (на вулиці, громадських місцях тощо). Для старших підлітків організовуються спеціальні профорієнтаційні заняття, а для підлітків з розумовою відсталістю функціонують центри професійної підготовки [9, c. 115-120].

Важливим завданням роботи перерахованих вище структур $з$ дітьми 3 інвалідністю є розвиток у таких дітей оптимального рівня незалежності в середовищі, а саме розвиток іiї фізичної, психічної та соціальної складової.

Соціальний працівник Департаменту соціальних служб Великобританії може надавати допомогу у вигляді консультацій, підтримки по особистих питаннях особи 3 інвалідністю та їх родин; розробляє індивідуальні програми реабілітації; займається організацією їх дозвілля.

Як було вище сказано однією із форм роботи з дітьми з інвалідністю є робота в домашніх умовах. Сюди зараховують послуги 3 ведення домашнього господарства (доставка харчів, прання) та послуги з довготривалої або короткотривалої опіки, які переважно надаються батькам, що займаються утриманням та вихованням дітей 3 
інвалідністю. Окремо існує послуга опіки над дітьми з інвалідністю під час відпустки батьків чи на вихідні. Деякі соціальні інституції пропонують реабілітаційні програми для дітей з інвалідністю та їх батьків, які перебувають у лікарні. А також існує послуга підтримки вдома для збільшення у дітей домашньої активності та безпеки.

Досить розповсюдженою у британській системі соціальної роботи 3 дітьми 3 інвалідністю $є$ використання концепції підготовки до незалежного життя. Дана концепція розглядається з двох позицій: перша - це підготовка особистості до того, що вона є повноправним членом суспільства та має право активно брати участь у його житті, а з іншої - формування навичок самостійного життя.

Для впровадження такої концепції створюються Центри незалежного життя, які виступають однією із моделей соціального обслуговування інвалідів. Часто такі центри організовуються громадами, вони можуть бути громадськими, некомерційними, управління може здійснюватися особами з інвалідністю. Частіше всього такі центри надають наступні види послуг: інформаційні (надання довідкової інформації) дітям та їх батькам; консультативні; індивідуальне консультування по захисту прав та інтересів осіб 3 інвалідністю та їх родичів; надання послуг (ведення домашнього господарства, підтримки у дома, організація дозвілля, послуги опіки) [3].

Прикладом такого центру у Великій Британії є центр незалежного життя у м. Глазго. Даний центр реалізує наступні проекти та надає такі види послуг: інформаційні (існує комп’ютерна база даних дітей з інвалідністю, центрів допомоги та їх реабілітації); тренінги для дітей з інвалідністю; програми по відновленню та захисту прав осіб з інвалідністю; заняття з профорієнтації; ресурсний центр для сліпих; заняття для громадян 3 формування толерантного ставлення до осіб 3 інвалідністю; юридична допомога та консультування; формування навичок самообслуговування та здобуття соціальних умінь (робити покупки, готувати їжу, користуватися громадськими місцями, поводитися з грішми тощо). У центрах організовуються заняття з малювання, рукоділля, фізкультури тощо [10, с. 209-211]. Такі центри є комплексною інноваційною моделлю системи соціальних служб, які створюють для людей з інвалідністю умови рівних можливостей. Ці центри допомагають людям з інвалідністю бути інформованими 3 питань їх прав та можливостей, з психологічних питань, з особистих питань та питань особистих інтересів тощо. Також Центри незалежного життя можуть надавати послуги 
особам з інвалідністю по догляду за домом, надання інформації про певні можливості для людей з інвалідністю, допомога в пересуванні та організації переїздів тощо. Такі центри спрямовані на надання інформаційної, юридичної допомоги, вирішують питання доступності та власності житла для осіб з інвалідністю, питання працевлаштування, впроваджують програми для підготовки молодих лідерів, що мають інвалідність та програми підготовки до незалежного життя.

Отже на рівні держави у Великій Британії існує ряд програм щодо роботи та надання соціальних послуг дітям з інвалідністю та їх сім'ям. Одна із таких програм є програма «Якість захисту» (Quality Protects programme). Вона спрямована на підтримку сімей, які виховують та доглядають за дітьми з інвалідністю. Програма забезпечує надання послуг з ведення домашнього господарства, домашньої допомоги. Крім цього пріоритетними завданнями даної програми є покращення результатів освіти дітей 3 інвалідністю, доступність закладів загальної середньої освіти для таких дітей, партнерське налагодження співпраці між соціальним працівником на рівні громади та 3 батьками які виховують дитину з інвалідністю, здійснення ранньої підтримки та втручання, програма забезпечує виділення коштів для оплати додаткових відпусток для батьків, що виховують дітей 3 інвалідністю. В рамках цієї програми функціонує національний інформаційний центр для сімей дітей з інвалідністю.

Ще однією державною програмою $є$ програма «Дія» (PROGRAMME OF ACTION). Ця програма спрямована на надання освітніх послуг дітям з інвалідністю, а саме: раннє виявлення та втручання, сприяти розкриттю потенціалу дітей з інвалідністю, забезпечення інклюзивності навчання, доступ до закладів загальної середньої освіти дітей з інвалідністю [4].

Не менш цікавою є британська програма, яка реалізується на державному рівні це програма «Охорони здоров’я в школах» (HEALTH CARE IN SCHOOLS). В рамках цієї програми передбачається підтримка з боку медичних та соціальних служб в школах. Заклади освіти в межах цієї програми зобов’язані погоджувати індивідуальний план охорони здоров’я $з$ шкільною медсестрою для здійснення діагностики індивідуальних потреб у здоров’ї дитини та для розробки навчальної програми для таких дітей враховуючи їх потреби та ефективному їх включенню у шкільне життя. 
У Великобританії на даний час найпоширенішим заходом щодо підтримки рівня життя людей з інвалідністю є надання певної матеріальної допомоги, різних пільг і дотацій. У більшості розвинутих країн допомога, що виплачується інвалідам, складається з двох частин: компенсація втраченого заробітку та відшкодування витрат на послуги, що пов'язані з інвалідністю. Так у Великобританії право на допомогу та ії розмір встановлюються залежно від віку особи, обсягу необхідної допомоги та ступеню непрацездатності (інвалідності).

Основними напрямами соціальної роботи 3 дітьми з інвалідністю у Великій Британії є: медико-соціальна робота, основний догляд (Community Care) надається переважно особам 3 розумовою відсталістю, особам 3 фізичними вадами, особам 3 проблемами психічного здоров'я; соціальна робота 3 дітьми та сім'ями (Children and Families' Social Work). Надається дітям з інвалідністю та сім'ям, що їх виховують. В межах даного напряму забезпечуються такі види соціальних послуг: няньки-вихователі, дитячі садки (денний догляд), дитячі садки та ясла (ігрові групи не на весь день), дитячі центри, підтримка в дома, групи/клуби продовженого дня, центри дозвілля, гуртожитки з наглядом, підтримка молодих батьків, які виховують дітей з інвалідністю, захист прав дітей з інвалідністю, клуби домашньої роботи, консультування у галузі навчання тощо.

Висновки. Таким чином нами було здійснено характеристику британської системи надання соціальних послуг дітям з інвалідністю та їх сім'ям. Система надання соціальних послуг даній категорії у Великій Британії містить поєднання медичної та соціальної моделей, які передбачають підготовку до самостійного життя осіб 3 інвалідністю та формування у них навичок самообслуговування. Вся система соціальної роботи з дітьми з інвалідністю у Великій Британії поєднує принцип підтримки таких осіб у всіх сферах суспільного життя.

Перспективними напрямами дослідження з обраної нами проблеми можуть стати виявлення умов організації соціальної роботи з дітьми з інвалідністю; обгрунтування змісту та форм підготовки фахівців соціальної роботи, виявлення чинників та факторів формування толерантного ставлення до осіб з інвалідністю.

\section{References}

1. Denesiuk O. Profesiina pidhotovka maibutnikh sotsialnykh pedahohiv ta fakhivtsiv sotsialnoi sfery do zdiisnennia sotsialno-pedahohichnoi pidtrymky batkiv, yaki vykhovuiut ditei 
$z$ invalidnistiu [Professional training of future social educators and social specialists for the implementation of socio-pedagogical support for parents raising children with disabilities]. Naukovi zapysky Nizhynskoho derzh. un-tu imeni M. Hoholia. 2016. No. 1. Pp. 173-177.

2. Derzhavna sluzhba statystyky. Sotsialnyi zakhyst naselennia Ukrainy [State Statistics Service. Social protection of the population of Ukraine]. Statystychnyi zbirnyk / vidpovidalna za vypusk Karmazina O.O. Kyiv. 2018. 121 p.

3. Komar I. Normatyvno-pravove zabezpechennia sotsialnoi roboty $z$ ditmy $z$ funktsionalnymy obmezhenniamy u Velykii Brytanii [Regulatory support for social work with children with disabilities in the UK]. Visnyk Chernihivskoho natsionalnoho ped. un-tu. Seriia pedahohichni nauky. Vol. 1. Issue 104. Chernihiv : ChNPU, 2012. Pp. 137-142.

4. Komar I. Sotsialna pidtrymka ditei iz funktsionalnymy obmezhenniamy u Velykii Brytanii [Social support for children with disabilities in the UK]. Pedahohichna osvita: teoriia i prakytyka. Psykholohiia. Pedahohika: zbirnyk nauk. prats. Kyiv: Kyivskyi un-t imeni Borysa Hrinchenka, 2013. No. 20. Pp. 58-62.

5. Liakh T., Spirina T., Rohozhynska V. Pryntsypy mizhdystsyplinarnoi vzaiemodii u sotsialnii roboti [Principles of interdisciplinary interaction in social work]. Aktualni pytannia humanitarnykh nauk. 2020. Vol. 3. No. 27. P. 224-228.

6. Petrochko Zh. Teoretyko-kontseptualni osnovy sotsialno-pedahohichnoho zabezpechennia prav ditei [Theoretical and conceptual foundations of socio-pedagogical support of children's rights.] Aktualni problemy derzhavnoho upravlinnia, pedahohiky ta psykholohii: zbirnyk naukovykh prats / za red. V. Butenko. Kherson : Khersonskyi NTU, 2011. Pp. 314-321.

7. Pet'ko L. V. Anhliys'ka mova dlya studentiv-psykholohiv ta defektolohiv. Dydaktychnyy material dlya praktychnykh zanyat' ta samostiynoyi roboty studentiv $z$ inozemnoyi movy zi spetsial'nostey: 6.010105 «Korektsiyna osvita (za nozolohiyamy)», 6.030102 «Psykholohiya», 6.030103 «Praktychna psykholohiya [English for students with specialization Psychology and Special Education". Didactic material for practical classes and independent work of students in a foreign language specialties 6.010105 "Special Education", 6.030102 "Psychology", 6.030103 "Practical Psychology" : navch. posibnik dlya studentiv ta vykladachiv VNZ. Kyiv : Talkom, 2015. 160 p.

8. Pet'ko L.V. Anhliys'ka mova dlya vstupnykiv do mahistratury zi spetsial'nosti 8.01010501 "Korektsiyna osvita (za nozolohiyamy)» [English for entrants to the master's degree in the specialty 8.01010501 "Correctional education (by nosology)"] : navch. posibnyk dlya studentiv, bakalavriv ta aspirantiv VNZ. - 3-ye vyd., stereotypne / L.V.Pet'ko, V.V.Nikolayenko, S.M.Dyshleva ; za red. Honcharova V.I., Syn'ova V.M. Kyiv : Un-t «Talkom», 2014. 199 p.

9. Piesha I., Mikheieva O. Porivnialna kharakterystyka pidhotovky sotsialnykh pedahohiv, shcho pratsiuiut $z$ pryiomnymy simiamy: ukrainskyi ta zakordonnyi dosvid [Comparative characteristics of training of social educators working with foster families: Ukrainian and foreign experience]. Visnyk Cherkaskoho un-tu. 2020. Issue 183. Vol. 2. Pp. 115-120.

10. Yarskaya-Smirnova E., Naberushkina E. Sotsialnaya rabota $s$ invalidami [Социальная работа с инвалидами]. Sankt-Peterburg. Piter. 2004. 316 p. P. 209-211. 
11. Children and Young People with Disabilities - July, 2018. P. 3

12. McLinden, M., Lynch, P., Soni, A. et al. Supporting Children with Disabilities in Low- and Middle- Income Countries: Promoting Inclusive Practice within Community-Based Childcare Centres in Malawi through a Bioecological Systems Perspective. IJEC 50, 159-174 (2018). https://doi.org/10.1007/s13158-018-0223-y

Translation of the Title, Abstract and References to the Author's Language УДК 364.4-056.26 - 053.2 (410)

\section{Британії.}

Різак І. Характеристика соціальної роботи 3 дітьми 3 інвалідністю у Великій

У статті охарактеризовано особливості соціальної роботи з дітьми з інвалідністю у Великій Британії. Визначено поняття діти з інвалідністю. Представлено трактування поняття діти 3 інвалідністю відповідно до медичної та соціальної моделі. Охарактеризовано основні структури, які можуть надавати соціальні послуги у Великій Британії дітям з інвалідністю. Проаналізовано та визначено особливості британської соціальної роботи 3 дітьми 3 інвалідністю в діяльності Центрів соціальних служб. Описано основні види соціальних послуг, що надаються такими центрами. Презентовано концепцію незалежного життя та діяльність центрів незалежного життя. Визначено види послуг, що надаються дітям з інвалідністю та сім'ям, що їх виховують (інформаційні; консультативні; юридичні; послуги ведення домашнього господарства, підтримки у дома, організація дозвілля, послуги опіки. Охарактеризовано програми, які впроваджуються на державному рівні для забезпечення підтримки та надання соціальної допомоги дітям 3 інвалідністю та сім'ям, що їх виховують. Проаналізовано спрямованість державних програм та забезпечення ними надання соціальних послуг щодо покращення результатів освіти дітей з інвалідністю, доступність закладів загальної середньої освіти для таких дітей, партнерське налагодження співпраці між соціальним працівником на рівні громади та з батьками які виховують дитину з інвалідністю, здійснення ранньої підтримки та втручання, програма забезпечує виділення коштів для оплати додаткових відпусток для батьків, що виховують дітей 3 інвалідністю. Охарактеризовано основні напрямами соціальної роботи 3 дітьми 3 інвалідністю у Великій Британії (медико-соціальна робота (основний догляд) та соціальна робота 3 дітьми та сім'ями.

Ключові слова: діти з інвалідністю, соціальні послуги, види соціальних послуг у Великій Британії, форми соціальної роботи 3 дітьми 3 інвалідністю, концепція незалежного життя, британські програми підтримки дітей з інвалідністю.

\section{Jimepamypa}

1. Денесюк О. Професійна підготовка майбутніх соціальних педагогів та фахівців соціальної сфери до здійснення соціально-педагогічної підтримки батьків, які виховують дітей з інвалідністю. Наукові записки Ніжинського державного університету імені М. Гоголя. 2016. №1. С. 173-177.

2. Державна служба статистики. Соціальний захист населення України. Статистичний збірник / Відп. за випуск Кармазіна О. О. Київ. 2018. 121 с. 
3. Комар I. Нормативно-правове забезпечення соціальної роботи 3 дітьми 3 функціональними обмеженнями у Великій Британії. Вісник Чернігівського національного педагогічного університету. Серія педагогічні науки. Том 1. Вип. 104. Чернігів : ЧНПУ, 2012. C. $137-142$.

4. Комар I. Соціальна підтримка дітей із функціональними обмеженнями у Великій Британії. Педагогічна освіта: теорія і пракитика. Психологія. Педагогіка: збірник наукових праць. Київ : Київський університет імені Бориса Грінченка, 2013. № 20. C. $58-62$.

5. Лях Т., Спіріна Т., Рогожинська В. Принципи міждисциплінарної взаємодії у соціальній роботі. Актуальні питання гуманітарних наук. 2020. Том 3. № 27. С. 224-228.

6. Петрочко Ж. Теретико-концептуальні основи соціально-педагогічного забезпечення прав дітей. Актуальні проблеми державного управління, педагогіки та психології: зб. наук. праць ; за ред. В. Бутенко. Херсон : Херсонський НТУ, 2011. С. 314-321.

7. Петько Л В. Англійська мова для студентів-психологів та дефектологів. Дидактичний матеріал для практичних занять та самостійної роботи студентів 3 іноземної мови зі спеціальностей: 6.010105 «Корекційна освіта (за нозологіями)», 6.030102 «Пихологія», 6.030103 «Практична психологія»: навч. посібник для студентів, магістрантів, аспірантів. Київ : Талком, 2015. 160 с.

8. Петько Л. В. Англійська мова для вступників до магістратури зі спеціальності 8.01010501 «Корекційна освіта (за нозологіями)»: навч. посібник для студентів, бакалаврів та аспірантів ВНЗ. - 3-є вид., стереотипне / Л.В.Петько, В.В.Ніколаєнко, С.М.Дишлева ; за ред. Гончарова В.І., Синьова В.М. Київ: Ун-т «Талком», 2014. 199 с.

9. Пєша I., Міхеєва О. Порівняльна характеристика підготовки соціальних педагогів, що працюють 3 прийомними сім'ями: український та закордонний досвід. Вісник Черкаського університету. 2010. Том 183. Вип. 2. С. 115-120.

10. Ярская-Смирнова Е., Наберушкина Э. Социальная работа с инвалидами. Санкт-Петербург : Питер. 2004. 316 с. С. 209-211.

11. Children and Young People with Disabilities - July, 2018. P. 3.

12. McLinden, M., Lynch, P., Soni, A. et al. Supporting Children with Disabilities in Low- and Middle- Income Countries: Promoting Inclusive Practice within Community-Based Childcare Centres in Malawi through a Bioecological Systems Perspective. IJEC 50, 159-174 (2018). https://doi.org/10.1007/s13158-018-0223-y 